\title{
Evaluating Safety Climate Impact on Safety Behaviour of the Worker in Small and Medium Entreprises (SMEs) Wood Furniture in Bandengan Village, Jepara
}

\author{
Novie Susanto ${ }^{1, *}$, Wiwik Budiawan ${ }^{1}$ and Ahmad Fardiansyah ${ }^{1}$ \\ ${ }^{1}$ Industrial Engineering Department, Faculty of Engineering, Diponegoro University, Semarang - Indonesia
}

\begin{abstract}
Small and Medium-sized wood furniture in Jepara is able to create jobs and employ about $40-50$ per cent of the 700,000 productive lives in Jepara. However, the results of the preliminary study show that 29 out of 30 people had experienced work accidents that caused injuries, such as: tear wounds, hammered hands, chiseled hands, sanded hands by machines. There are also occupational diseases such as breathless, eye irritation, skin irritation due to sawdust of production process, as well as musculoskeletal disease. This study aims at evaluating the influence of safety climate to safe work behavior. Data is collected using Safety Climate Questionnaire (SCQ) including 6 variables (Communication \& Support, Adequacy of Procedures, Work Pressure, Personal Protective Equipment, Relationships \& Safety Rule). There are 110 respondents (represent small-sized enterprise worker) and 210 respondents (represent medium-sized enterprises worker). This study also differs the small and medium sized-enterprises as the independent variable. The descriptive test results show that every variable of safety climate and safety behavior in medium Enterprises has a mean value greater than in small business. The six factors in the safety climate together have a significant influence on safety behavior in small and medium enterprises.
\end{abstract}

Keywords: safety climate, behavior, SMEs, wood furniture, Jepara

\section{Introduction}

Over the past 30 years, Small and Medium Enterprises (SMEs) have gained increasing recognition as a form of legitimate economic activity throughout the world with the potential to contribute to economic prosperity as well as social development [1]. In Indonesia, SMEs have become the biggest advocates for sustainable development and an important means of absorbing labor. In fact, SMEs have an employment rate of about $97 \%$ of the total national workforce and contribute to $57 \%$ of gross domestic product (GDP) [2]. However, SMEs still face various challenges. One of them is how to improve productivity, while at the same time improving occupational safety and health as well as working conditions.

According to data from Institution of Social Security Employment (Badan Penyelenggara Jaminan Sosial Ketenagakerjaan/BPJS Ketenagakerjaan), the number of occupational accidents in Indonesia currently reaches 105,185 cases in 2015 , with casualties reaching 2,375 people. Therefore, Occupational Safety and Health is an important aspect in the production process, especially for small and medium enterprises (SMEs) that employ more than $95 \%$ of the working population in the world. The ILO director, Peter van Rooij, said that SMEs are the key to creating and developing decent work for all. The results show that those who work in Small and Medium Enterprises are more often exposed to dangerous situations and suffer more work-related illnesses than those who work in larger businesses [3-6]. In addition, according to Nina Tursinah as Chairman of the Employers Association of Indonesia (APINDO) SME Field, it is said that safety in the field of SMEs is needed because almost $70 \%$ of the employee are lack of safety education and it affects productivity competitiveness. Therefore, the application of occupational health and safety effectively and efficiently is very important for improving the productivity and competitiveness of SMEs in Indonesia.

Small and Medium Enterprises Furniture in Jepara is already a "vein" for the people of Jepara. The industry is able to create jobs and employ about $40-50$ per cent of the 700,000 productive lives in Jepara [7]. Furniture products are still a mainstay for Central Java Province, in addition to textile products [8]. The contribution of Gross Regional Domestic Product (PDRB) of teak furniture in 2010 is the highest compared to other industry PDRB value, which is more than $22.65 \%$ [7]. Those who are behind this fact are the workers or furniture craftsmen. However, behind the growth and

* Corresponding author: novie.susanto@ft.undip.ac.id 
contribution of wood processing industries in Central Java, especially in Jepara regency, there are still some risks of accidents.

The results of the preliminary study showed that 29 out of 30 people had experienced work accidents that caused injuries, such as: tearing wounds, hammered hands, chiseled hands, hands were sanded by machines. There were also 14 occupational diseases experiencing shortness of breath, 8 people have eye irritation and 21 people get skin irritation due to wood powder production process. All respondents have experienced musculoskeletal disease due to repetitive and too much work, as well.

The facts indicate that the working conditions of the wood processing industry generally have the risk of accidents and health problems due to the influence of the nature of the work, the characteristics of workers, and the safety culture and the use of harmful machines and poorly spaced layout. it also contributes on enviromental condition in the location area Workers are always exposed to wood dust particles, noise from the use of machine tools such as saws, electric shrinking machines, grinding and drilling, and exposure to chemicals in color coating activities in the furniture finishing stage beyond the permitted threshold. In addition, the use of machine tools associated with handling, storing, lifting and transporting loads manually that is repetitive to cause musculosceletal diseases [9].

Based on research conducted by the National Safety Council (NSC) in 2011, it mentioned the result that the cause of occupational accidents is $88 \%$ due to unsafe behavior, $10 \%$ due to unsafe condition, and $2 \%$ unknown cause. [10] also states that most of the causes of occupational accidents are due to unsafe behavior with a percentage of $80-95 \%$. In addition, data from the Safety Intervention Strategies results by the National Safety Council also show that Behavior-Based Safety (BBS) has shown the success rate in the first rank and means that achieving the highest reduction of work accident, that is, the percentage of $59,6 \%$ done on 7 research and 2,444 subject.

According to [11], safe behavior can be seen from the behavior of workers when doing their work at work. BBS approach will be more successful if it supported by approaches and methods that encourage increased behavior change from unsafe to safe behavior as an effort to prevent accidents. It also can contribute to form a better environment for example to reduce the carbon production during production process.

The safety climate has a definition of workers' common perceptions of management and safety policies, procedures, and practices at any given time [12]. The safety climate can be used as an antecedent of safety performance within an organization [13-14] and is also an observable cultural safety manifestation [15], and can predict workers' safe behavior [16-17]. This study aims to analyze the influence of Safety Climate factors on Safety Behavior on furniture workers and to know the working safety climate in Small and Medium Enterprises in Jepara Regency.

\section{Methods}

This study started from a field study that conducted by survey of 30 workers who were randomly selected. They were assigned to work accidents they had experienced using open questions about the type of accident and cause of the accident. This research used research model according to [17] with independent variable: Communication \& Support, Adequacy of Procedures, Work Pressure, PPE, Relationships, Safety Rules and dependent variable Safety Behavior. Figure 1 shows the research model used.

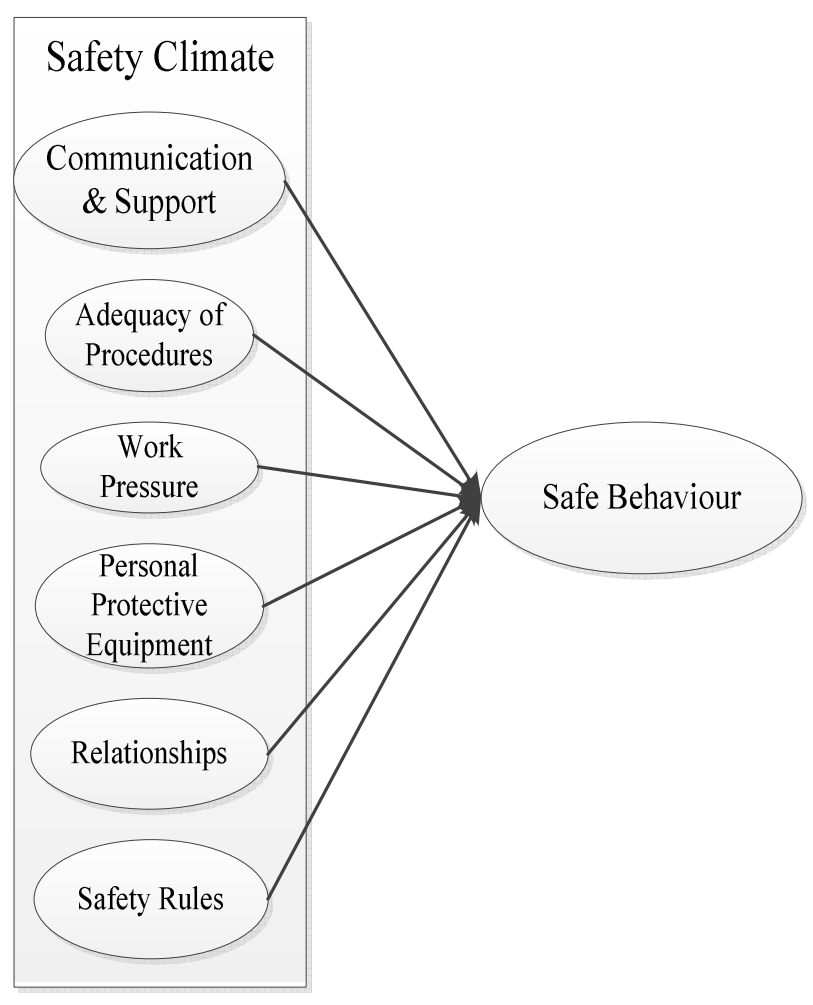

Fig 1. Research Model

Questionnaire formation is performed to obtain the respondent profile data and the indicator of research variables as listed in Table 1.

There are a total of 320 respondents in this study divided into 110 respondents representing small-sized enterprises (SI) and 210 respondents representing medium-sized enterprises (MI). ANOVA and multiple linear regression tests were used for statistical testing of the data obtained. The results of data processing are used as a source of design interventions needed to improve workers' safe behavior.

\section{Result and Discussion}

\subsection{Hasil Uji ANOVA}

Hasil uji ANOVA untuk variabel-variabel penelitian dapat dilihat pada Table 2. 
Table 1. Variables and questionnaire

\begin{tabular}{|c|c|c|}
\hline Variable & & Statement \\
\hline \multirow{6}{*}{$\begin{array}{l}\text { Communication \& } \\
\text { Support (A) }\end{array}$} & A1 & Every problem in work is always discussed between worker and boss/management \\
\hline & A2 & Workers are always socialized when there are changes in safety regulations \\
\hline & A3 & Workers are always discussing important issues about the safety policy \\
\hline & A4 & Changes in work procedures and their effects on safety are always communicated to workers \\
\hline & A5 & Workers are always encouraged to support each other \\
\hline & A6 & Potential risks and consequences have been identified and always submitted by employees \\
\hline \multirow{5}{*}{$\begin{array}{l}\text { Adequacy of } \\
\text { Procedures (B) }\end{array}$} & B1 & Work procedure is complete and comprehensive \\
\hline & B2 & Working procedures are clearly written \\
\hline & B3 & Written work procedures are always consistent with the practice \\
\hline & B4 & Workers can easily identify the relevant procedures for each job \\
\hline & B5 & $\begin{array}{l}\text { There is documentation ensuring the availability of equipment related to safety according to the } \\
\text { procedure }\end{array}$ \\
\hline \multirow{5}{*}{ Work Pressure C } & $\mathrm{C} 1$ & $\begin{array}{l}\text { There is sufficient 'thinking time' for me in planning and carrying out my work to an adequate } \\
\text { standard }\end{array}$ \\
\hline & $\mathrm{C} 2$ & In completing a job, I feel the number of workers is enough \\
\hline & $\mathrm{C} 3$ & I have enough time to finish the job \\
\hline & $\mathrm{C} 4$ & The time required to complete a work order is considered realistic \\
\hline & $\mathrm{C} 5$ & I feel the workload is quite balanced \\
\hline \multirow{3}{*}{$\begin{array}{l}\text { Personal Protective } \\
\text { Equipment (D) }\end{array}$} & D1 & Personal protective equipment used is always controlled to find whether if there is a problem \\
\hline & $\mathrm{D} 2$ & Findings and monitoring of damaged Personal Protective Equipment are immediately followed up \\
\hline & D3 & Workers always use Personal Protective Equipment \\
\hline \multirow{3}{*}{ Relationships (E) } & E1 & I am confident about my future in my workplace \\
\hline & E2 & My workplace has a good working relationship between workers \\
\hline & E3 & I am always passionate when I am doing work \\
\hline \multirow{3}{*}{ Safety Rule (F) } & $\mathrm{F} 1$ & Safety regulations are always easy to implement \\
\hline & $\mathrm{F} 2$ & $\begin{array}{l}\text { Safety regulations relating to the safety of workers may be followed without conflict with work } \\
\text { practices }\end{array}$ \\
\hline & F3 & Safety rules relating to the safety of workers are done without haste \\
\hline $\begin{array}{l}\text { Safety Behaviour } \\
(\mathrm{G})\end{array}$ & G1 & I use all the safety equipment needed to do my work \\
\hline
\end{tabular}

Table 2. ANOVA Test result

\begin{tabular}{|c|c|c|c|c|c|}
\hline $\mathrm{Nr}$ & Variable & SI & MI & Sig. & Information \\
\hline 1 & A & 3.036 & 4.024 & 0.007 & Significant \\
\hline 2 & B & 3.100 & 3.937 & 0.001 & Significant \\
\hline 3 & C & 2.442 & 3.399 & 0.166 & Significant \\
\hline 4 & D & 2.752 & 3.723 & 0.000 & Significant \\
\hline 5 & E & 2.830 & 3.775 & 0.805 & Not Significant \\
\hline 6 & F & 2.930 & 3.811 & 0.207 & Not Significant \\
\hline 7 & G & 3.196 & 4.210 & 0.127 & Not Significant \\
\hline
\end{tabular}

Based on the results of Linear Regression Test using SPSS, it is obtained the following regression equation:

$\mathrm{Y}=0.218+0.383 \mathrm{X}_{1}+0.290 \mathrm{X}_{2}-0.258 \mathrm{X}_{3}+0.267 \mathrm{X}_{4}+$ $0.067 \mathrm{X}_{5}+0.236 \mathrm{X}_{6}+\mathrm{e}$.
Based on the above equation, it can be seen the variables Communication \& Support, Adequacy of Procedures, Personal Protective Equipment, Relationships, \& Safety Rule showed positive regression results. It means there is a positive or unidirectional

\footnotetext{
*orresponding author: novie.susanto $@$,ft.undip.ac.id
} 
influence between independent variables with dependent variable. The work pressure shows the value of negative regression coefficient, meaning with the occurrence of decrease in work pressure can improve the safe work behavior of the workers.

In medium-sized enterprises, it is known that Communication \& Support factor has $\mathrm{t}$ value of 10.523 with a significance value of 0.000 and small-sized enterprises have $\mathrm{t}$ value of 6.994 with a significance value of 0.000 . It shows that this variable has a significant positive effect on Safety Behavior in Small and Medium Enterprises. The increase of Communication \& Support variable will increase the safety behaviour. The positive effect of Communication \& Support on Safety Behavior is also in line with [18] which states the importance of communication and social support. Workers are more affected during daily interactions with supervisors and co-workers themselves.

In medium-sized enterprises, it is known that Adequacy of Procedures factor has $t$ value of 6.976 with a significance value of 0.000 and small-sized enterprises have $t$ value of 2.986 with a significance value of 0.004 . It shows that this variable has a significant positive effect on Safety Behavior in Small and Medium Enterprises. The increasing Adequacy of Procedures variable will also increase Safety Behavior of workers. This is in line with [19] study which states that work procedures relate directly to the safe working behavior of construction workers.

In medium-sized enterprises, it is known that Work Pressure factor has $t$ value of -11.485 with a significance value of 0.000 and small-sized enterprises have $t$ value of -7.106 with a significance value of 0.000 . It shows that this variable has a significant negative effect on Safety Behavior in Small and Medium Enterprises. The decreasing of work pressure variable will increase the safety behaviour. This result is inline with some studies $[19,20-24]$ which states that workers behave insecure not because they do not understand the risks involved, but because of the pressure of work provided by supervisors and managers.

In medium-sized enterprises, it is known that Personal Protective Equipment (PPE) factor has $t$ value of 10.911 with a significance value of 0.000 and smallsized enterprises have $t$ value of 10.755 with a significance value of 0.000 . It shows that this variable has a significant positive effect on Safety Behavior in Small and Medium Enterprises. The increasing of work pressure variable will increase the safety behaviour. This is in line with the opinion of [12]. The result of intervention by improving the condition of PPE and the availability of PPE can increase the behavior of the workers.

In medium-sized enterprises, it is known that Relationship factor has $t$ value of 1.624 with a significance value of 0.106 and small-sized enterprises have $t$ value of 1.535 with a significance value of 0.128 . It shows that this variable has not significant effect on Safety Behavior in Small and Medium Enterprises. This is in line with the opinion of [25] that stated workers in organizations generally consider themselves as members of the group. The relationships in this group contribute to the Safety Climate Perception, and consequently also affect the Safety Behavior.

Based on the results of interviews to the Labor Office and the Industry Labor of Jepara and the result of the evaluation of the intervention in previous research, it can be given recommendations on Small and Medium Enterprises as follows.

1. As an effort to improve Communication and Support factor, it can be performed by providing information about feedback and input between worker with supervisor on daily activity. This is in line with the opinion of [26] which states that feedback and feedback information can improve Safety Climate so it can also improve Safety Behavior. It can also be enhanced by mounting displays or posters on the importance of Safety. This is also in line with the results of interviews with the Labor Office related to the condition of these variables. There are lacking of communication function and support on the safety of the management level and supervisor of the workers for the SMEs.

2. The Adequacy of Procedures factor can be enhanced by efforts such as training workers on occupational health and safety procedures. This is also in line with the statement from the results of interviews with the Labor Office in Jepara District who judge the current furniture workers do not understand about the working procedures and needs to be improved again. It can be achieved by installing Works Instruction Sheets at each work station, so that workers can better understand what to do and avoid when doing the job.

3. Work Pressure factors can be improved by optimizing the number of employees in accordance with the existing workload. Based on interviews with SME owners, they acknowledge that when there are many requests, they increase the number of workers, but it is actually still insufficient to meet demand, so the overtime is applied.

4. Personal Protective Equipment factors can be improved by conducting routine inspections of existing PPE conditions. It is also shown based on the results of observation it is found some damages masks and lacking number of gloves

5. Relationships factors can be improved by conducting Safety Meetings once a week before work. Safety Meetings is a tool for employer and workers to improve relationships and exchange knowledge about the implementation process of work safety in the organization ([14].

6. Safety Rule Factor can be improved by socializing Safety regulations that need to be followed. Supervisory function after the implementation of the regulation also need to be improved [9].

Design of intervention model for Safety Climate that can also improve Safety Behavior can be seen in Figure 2. 


\section{Conclusion and Further Studies}

Descriptive test results show that every variable of Safety Climate and Safety Behavior in Medium Enterprises has a mean value greater than in Small Enterprises. The six factors in the safety climate (Communication \& Support, Adequacy of Procedures, Work Pressure, Personal Protective Equipment, Relationships \& Safety Rule) together have a significant influence on safety behavior in Small and Medium Enterprises. Steps that can be performed are: installation of diplay and poster $\mathrm{OSH}$, basic work procedure, $\mathrm{OSH}$ training, installation of work instruction sheet, routine safety meetings once a week before work, performing job enrichment to worker to supervise condition and execution of PPE and socializing OSH implementation.

The topic for futher study is the implementation of the intervention model implementation and evaluate the results of the implementation of the model. Besides, to validate the model, it can also applied in other SMEs such as batik, fish proceesing, or others.

\section{Acknowledgement}

This research was financially supported by The Faculty of Engineering, Diponegoro University, Indonesia through Strategic Research Grant 2018.

\section{References}

1. S. Legg, I. Laid, K.B. Olsen, P. Hasle, 2014 Int. J. Small Enterprise. Res. 21(2), 139-147 (2014).

2. Bank Indonesia, 2015, Profil Bisnis Usaha Mikro, Kecil dan Menengah (UMKM). LPPI: Jakarta

3. T.R.Cunningham and R. Sinclair. Safety Science 71(100):213-225 (2015).

4. E. Cagno, G. J. L. Micheli, S. Perotti. Safety Science 49(2), 216-225 (2011).

5. O.H. Sorensen, P. Hasle, P and E. Bach. Safety science 45(10), 1044-1059 (2007).

6. A. Targoutzidis, T. Koukoulaki, E. SchmitzFelten, K. Kuhl, K.M.O Hengel, E. Rijken. The business case for safety and health at work: Cost-benefit analyses of interventions in small and medium-sized enterprises. Luxembourg: European Agency for Safety and Health at Work (2014).
7. BPS. Situasi Kesehatan Kerja. Pusat Daya dan Informasi Kementrian Kesehatan RI (2015).

8. ILO. Global Strategy on Occupational Safety and Health. ILO (2004).

9. Health and Safety Executive. Example Risk Assessment for A Woodworking Company. (2007)

10. M.D. Cooper. Professional Safety. June 2002, 30-36 (2002).

11. E.S. Geller. Working Safe: How to Help People Actively Care for Health and Safety. 2nd Edition. USA, CRC Press LLC (2001).

12. D. Zohar and O. Tenne-Gazit. Journal of Applied Psychology 93(4), 744-57 (2008).

13. M.S.Christian, J.C Bradley-Geist, C. Wallace and M. Burke. Journal of Applied Psychology 94(5), 1103-27 (2009)

14. A. Neal and M.A. Griffin. Australian Journal of Management 27, 67-75 (2002).

15. K. Mearns and S. Yule Safety Science 47(6), 777-785 (2009).

16. D.V.Day. The climate and culture of leadership in organizations. The Oxford handbook of organizational climate and culture. Chapter: The climate and culture of leadership in organizations. Oxford University Press. Editors: B. Schneider \& K.M Barbera (2014).

17. A.I. Glendon and D.K Litherland. Safety Science 39, 157-188 (2001).

18. H. Lingard, T. Cooke, N. Blismas, N. J. Constr. Eng. Management. 138 (2) (2012).

19. S. Mohamed. J. Constr. Eng. Management. 128, 375-384 (2002).

20. R.M. Choudhry and D. Fang. Safety science 46(4), 566-584 (2008).

21. R. Flin, K. Mearns, P.O Connor and R. Bryden. Safety Science 34(1), 177-192 (2000).

22. S. Han, F. Saba, S. Lee, Y. Mohamed, F. PeñaMora. Toward an understanding of the impact of production pressure on safety performance in construction operations. Accident Anal. Prevention (2013).

23. J. J. Mullen. Safety Res. 35(3), 275-85 (2004).

24. D.C Seo. Safety Science. 43, 187-211 (2005).

25. G.J.Fogarty and A. Shaw. Accid Anal Prev. 42(5), 1455-9 (2010).

26. P. Kines, J. Lappalainen, K.L. Mikkelsen, E. Olsen, A. Pousette, J. Tharaldsen, K.Tomasson and M. Torner. International Journal of Industrial Ergonomics 41, 634-646 (2011). 